\title{
Acute Toxicological and In-vivo Anxiolytic Activity Screening of Aqueous and Chloroform Fractions of Hydroalcoholic Tapinanthusglobiferus Leaf Extracts
}

\author{
Umarudeen A. M., Aminu C
}

\begin{abstract}
Extracts of Tapinanthus globiferus and related species are being increasingly used as traditional remedies for diverse diseases including diabetes mellitus, hypertension and nervousness. Yet, scientific reports on the safety and efficacy of extracts and fractions of these medicinal plants are sparse. Theaim of the current study is to investigate the acute toxicological and anxiolytic activities of the fractions obtained from the hydroalcoholic Tapinanthus globiferus leaf extracts (HTG) by Lorke's method and standard behavioural assays, respectively.Fractionation of HTG yielded mainly aqueous and chloroform fractions. Both fractions had LD50 greater than $5000 \mathrm{mg} / \mathrm{kg}$ (oral route). Both extract fractions also demonstrated significant $(P<0.05)$ anxiolytic activities when compared to the negative control on most anxiety parameters in both open-field and elevated zero-maze tests. However, the aqueous residue fraction exhibited superior anxiolytic activity over the chloroform fraction. These findings suggest that aqueousand chloroform fractions are safe and possess anxiolytic activity, and need be developed further as alternative anti-anxiety agents.
\end{abstract}

Index Terms - anxiolytic activity, selected medicinal plants, test battery, mice.

\section{INTRODUCTION}

Tapinanthus globiferus is one of the several species belonging to a genus of mistletoe found within the family Loranthaceae. These species, commonly referred to as all-heal, bird lime, cure-all or devil's fuge, have been shown to have-widespread distribution in Africa with over thirty members of this family fully identified $(1,2)$. Other more commonly species of this family includeTapinanthus banwensis, Tapinanthus dodoneifolius, Tapinanthus oleifoliusand Tapinanthuscoronatus(2).These hemiparasitic plants are commonly seen on host trees such as Parkiabiglobosa, Acacia nilotica and Azardirachtaindica(Neem) in Sokoto, Sokoto State, Nigeria, where they are given the native name 'Kauchi'. In the South-western region of Nigeria, they are called 'Afomo' by the Yorubas, and they commonlyparasitize Cocoa, Kolanut and Cashew trees $(3,4,5)$.

Tapinanthus globiferus and its congeners have been reported with ethno-medicinal efficacies in diseases such as

Umarudeen A. M., Department of Pharmacology \& Therapeutics, Faculty of Basic Clinical Sciences, College of Health Sciences, University of Abuja, Federal Capital Territory, Abuja, Nigeria

Aminu C, Department of Pharmacology \& Therapeutics, Faculty of Basic Clinical Sciences, College of Health Sciences, Usman Danfodiyo University, Sokoto, Sokoto State, Nigeria nervous disorders, hypertension, diabetes mellitus, fever, cancer and epilepsy (6)(7). These medicinal plants have also been reported to exhibit anti-lipidemic, hypoglycemic (6), antihypertensive and diuretic (7), antimicrobial (8), anti-oxidant (9), anti-inflammatory and hepatoprotective (10) properties in previous studies. Abubakar and Adebisi (11) have reported anticonvulsant effect of an aqueous residue fraction and Shehu et al. (12) have demonstrated antidepressant activity of methanol leaf extract of Tapinanthus globiferus leaves in mice. Anxiolytic and antidepressant activities have also been reported for a crude aqueous Tapinanthus globiferus stem bark extract in mice (13) just as animal studies have indicated anxiolytic effects for leaf extract of Azadirachta indica(14) - the host tree from which the Tapinanthus globiferus leaves for the present study was collected. But in spite of the anecdotal reports of widespread use of this Tapinanthus specie in Sokoto and environs, there has not been any scientific report on the acute anxiolytic and acute toxicological effects of fractions obtained from leaf extracts of Tapinanthus globiferus grown on Azadirachta indica. This study, therefore set out to determine the acute toxicological and anxiolytic activity of the fractions obtained from the plant's leaf extract.

\section{MATERIALS AND METHOD}

\section{Drugs and Reagents}

Diazepam (Roche) and analytical grades of n-hexane, chloroform, butanol and ethyl acetate were purchased from cardinal Scientific supplies, Sokoto road, Zaria, Kaduna State.

\section{Extract preparation and partitioning}

Solvent-solvent partitioning of the crude methanol Tapinanthus globiferus leaf extract was carried out according to the method described by Kupchan and Tsou (15).Fifty-five grams $(55 \mathrm{~g})$ of dry crude methanol Tapinanthus globiferus leaf extract was dissolved in $200 \mathrm{ml}$ of aqueous methanol (water/methanol: 30/70) to produce the stock solution which was successively partitioned with $\mathrm{n}$-hexane, chloroform, ethyl acetate and n-butanol in order of increasing polarity in a separating funnel. Subsequently, all fractions obtained were air-dried withthe exception of the aqueous residue fraction which was freeze-dried.

Acute toxicity testing

Acute toxicity testing of the fractions obtained from crude methanol Tapinanthus globiferus leaf extract was carried out in female Swiss Albino mice (oral) according to the method described by Lorke(16) 


\section{Behavioural studies}

The in-vivo anxiolytic activities of the fractions of the crude aqueous methanol Tapinanthus globiferus leaf extract were determined by the use of a test battery of open-field and elevated zero-maze tests in an experimental setup similar to the arrangement previously described by Schmitt and Hiemke (17) - but with a modification of minimal/nil delays between the two tests. Randomized groups $(\mathrm{n}=12)$ of male mice were given i.p.administration of 50,100 or $200 \mathrm{mg} / \mathrm{kg}$ of plant extracts, $0.5 \mathrm{mg} / \mathrm{kg}$ diazepam or $10 \mathrm{ml} / \mathrm{kg}$ distilled water, and forty-five minutes after the last drug administration, they were each exposed to a battery of open-field and elevated zero-maze situated in opaque cubicles having 100-lux illumination. Each run of behavioural assay was begun by placing each mouse in the centre of the open field and allowed to freely move and explore the field for 5 minutes. At the end of this period, each mouse was again transferred to the mid-point of an open segment of the elevated zero-maze with the mouse facing one of the closed segments. The animal was allowed to freely explore its new environment for 5 minutes. Animals that jumped off the open segment of the zero maze during the procedure were gently returned immediately to the test.

All test sessions were videotaped visually monitored. Data were analyzed using analysis of variance (ANOVA) followed by Turkey post hoc test. $P$-values less than 0.05 were considered as significant.

\section{RESULTS}

\section{Extract preparation and partitioning}

Fifty (55) gramme of crude aqueous methanol Tapinanthus globiferus leaf extract subjected to fractionation partitioned majorly into distilled water $(78.89 \%)$, fairly into chloroform $(11.18 \%)$ and negligibly, into hexane $(1.13 \%)$, butanol $(0.73 \%)$ and acetyl acetate $(0.64 \%)$ (Table 1$)$.

\section{Acute toxicity testing}

$\mathrm{LD}_{50 \mathrm{~s}}$ for both the aqueous and chloroform fractions of the
hydroalcoholicTapinanthus globiferus leaf extract in mice were greater than $5000 \mathrm{mg} / \mathrm{kg}$.

\section{Behavioural results}

Administration of aqueous residue fraction of methanol Tapinanthus globiferus leaf extract (ARFTG) and chloroform fraction of methanol Tapinanthus globiferus leaf extract (CFTG) in mice at 50, 100 and $200 \mathrm{mg} / \mathrm{kg}$ elicited differential behavioural results. ARFTG treatment caused significant ( $p<$ 0.05 ) alterations in all the anxiety parameters evaluated i.e. mean percentage centre zone (\%CZT) and percentage open segment (\%OST) time, mean rears and stretch-attend postures (SAPs), CFTG treatment failed to demonstrate significant $(p>0.05)$ increase in one of the open-field parameter i.e. mean \%CZT when compared with the negative control treatment.

On the mean rearing frequency, ARFTG a greater dose-dependent reduction in the rearing frequency of the untreated mice $(36.50 \pm 6.16)$ tothe best mean rears value of $6.50 \pm 1.97$ at $200 \mathrm{mg} / \mathrm{kg}$ dose level compared to CFTG that caused a reduction in this value $(36.50 \pm 6.16)$ to only $14.18 \pm 3.53$ at the $200 \mathrm{mg} / \mathrm{kg}$ dose level.

On the \%OST, ARFTG displayed greater dose-dependent anxiolytic activity compared to the inverted U-shaped anxiolytic activity of CFTG.

On the number of stretch-attend postures (SAPs), again, ARFTG-treated mice exhibited greater and dose dependent reductions in the frequency of manifestation of this anxiety parameter compared to CFTG. The best mean SAPs $(1.42 \pm 0.50)$ of ARFTG is about three-fold better than the CFTG's best mean SAPs of $1.42 \pm 0.50$.

\begin{tabular}{|l|l|l|l|}
\hline \multicolumn{2}{|c|}{ Table 1: Per cent yields of fractions from methanol Tapinanthusglobiferus leaf extract } \\
\hline Solvent & Weight $(\mathrm{g})$ & $\%$ weight $(\mathrm{g} / 100 \mathrm{~g})$ & Colour \\
\hline Hexane & 0.62 & 1.13 & Oily green \\
\hline Chloroform & 6.15 & 11.18 & Bright green \\
\hline Ethyl acetate & 0.35 & 0.64 & Light brownish \\
\hline Butanol & 0.40 & 0.73 & Greenish brown \\
\hline Aqueous & 42.18 & 76.69 & Dark brown \\
\hline Total & 49.70 & 90.37 & \\
\hline
\end{tabular}

\begin{tabular}{|l|l|l|l|}
\hline \multicolumn{4}{|l|}{ Table 2: Per cent centre zone time of mice on open-field test } \\
\hline \multirow{2}{*}{ Treatment groups } & Extracts' doses & $\mathbf{2 0 0 m g / ~} \mathbf{~ g}$ \\
\cline { 2 - 4 } & $\mathbf{5 0 m g / ~} \mathbf{~ k g}$ & $\mathbf{1 0 0} \mathbf{m g} / \mathbf{~ k g}$ & $3.31 \pm 0.79$ \\
\hline D/water $(10 \mathrm{ml} / \mathrm{kg})$ & $3.31 \pm 0.79$ & $3.31 \pm 0.79$ & $8.97 \pm 4.05^{*}$ \\
\hline ARFTG & $4.36 \pm 0.93$ & $5.12 \pm 1.02$ & $5.09 \pm 1.42$ \\
\hline CFTG & $4.44 \pm 1.09$ & $5.47 \pm 1.21$ & $13.21 \pm 3.38^{*}$ \\
\hline Diazepam $(0.5 \mathrm{mg} / \mathrm{kg})$ & $13.21 \pm 3.38^{*}$ & $13.21 \pm 3.38^{*}$ & \\
\hline
\end{tabular}

Data were entered as mean \pm S.E.M of mice. $*$ Statistically significant $(p<0.05)$.

ARFTG, aqueous residue fraction of Tapinanthus globiferus leaf extract;

CFTG; chloroform fraction of Tapinanthus globiferus leaf extract. 


\begin{tabular}{|c|c|c|c|}
\hline \multirow[t]{2}{*}{ Treatment groups } & \multicolumn{3}{|c|}{ Extracts' doses } \\
\hline & $50 \mathrm{mg} / \mathrm{kg}$ & $100 \mathrm{mg} / \mathrm{kg}$ & $200 \mathrm{mg} / \mathrm{kg}$ \\
\hline $\mathrm{D} /$ water $(10 \mathrm{ml} / \mathrm{kg})$ & $36.50 \pm 6.16$ & $36.50 \pm 6.16$ & $36.50 \pm 6.16$ \\
\hline ARFTG & $8.08 \pm 1.92 *$ & $7.73 \pm 2.53 *$ & $6.50 \pm 1.97 *$ \\
\hline CFTG & $15.50 \pm 3.78^{*}$ & $13.58 \pm 2.99 *$ & $14.18 \pm 3.53^{*}$ \\
\hline Diazepam $(0.5 \mathrm{mg} / \mathrm{kg})$ & $8.91 \pm 3.31 *$ & $8.91 \pm 3.31 *$ & $8.91 \pm 3.31 *$ \\
\hline
\end{tabular}

Data were entered as mean \pm S.E.M of mice. ${ }^{*}$ Statistically significant $(\mathrm{p}<0.05)$.

ARFTG, aqueous residue fraction of Tapinanthus globiferus leaf extract;

CFTG; chloroform fraction of Tapinanthus globiferus leaf extract.

\begin{tabular}{|c|c|c|c|}
\hline \multirow{2}{*}{ Treatment groups } & \multicolumn{3}{|c|}{ Extracts' doses } \\
\hline & $50 \mathrm{mg} / \mathrm{kg}$ & $100 \mathrm{mg} / \mathrm{kg}$ & $200 \mathrm{mg} / \mathrm{kg}$ \\
\hline $\mathrm{D} /$ water $(10 \mathrm{ml} / \mathrm{kg})$ & $7.58 \pm 1.55$ & $7.58 \pm 1.55$ & $7.58 \pm 1.55$ \\
\hline ARFTG & $10.52 \pm 1.74$ & $16.91 \pm 2.02 *$ & $18.78 \pm 3.09^{*}$ \\
\hline CFTG & $13.11 \pm 1.80^{*}$ & $16.19 \pm 3.52 *$ & $11.11 \pm 2.31$ \\
\hline Diazepam $(0.5 \mathrm{mg} / \mathrm{kg})$ & $19.45 \pm 3.44 *$ & $19.45 \pm 3.44 *$ & $19.45 \pm 3.44 *$ \\
\hline
\end{tabular}

Data were entered as mean \pm S.E.M of mice. ${ }^{*}$ Statistically significant $(\mathrm{p}<0.05)$.

ARFTG, aqueous residue fraction of Tapinanthus globiferus leaf extract;

CFTG; chloroform fraction of Tapinanthus globiferus leaf extract

\begin{tabular}{|l|l|l|l|}
\hline \multicolumn{4}{|l|}{ Table 5: Number of stretch-attend postures of mice on elevated zero-maze } \\
\hline \multirow{2}{*}{ Treatment groups } & Extracts' doses & $\mathbf{2 0 0 m g / ~}$ \\
\cline { 2 - 4 } & $\mathbf{5 0 m g} / \mathbf{~ k g}$ & $\mathbf{1 0 0} \mathbf{m g} / \mathbf{~ k g}$ & $16.08 \pm 2.91$ \\
\hline D/water $(10 \mathrm{ml} / \mathrm{kg})$ & $16.08 \pm 2.91$ & $16.08 \pm 2.91$ & $1.42 \pm 0.50^{*}$ \\
\hline ARFTG & $3.00 \pm 1.21^{*}$ & $1.82 \pm 0.65^{*}$ & $4.00 \pm 0.75^{*}$ \\
\hline CFTG & $4.50 \pm 1.43^{*}$ & $2.83 \pm 0.77^{*}$ & $4.27 \pm 0.75^{*}$ \\
\hline Diazepam $(0.5 \mathrm{mg} / \mathrm{kg})$ & $4.27 \pm 0.75^{*}$ & $4.27 \pm 0.75^{*}$ & \\
\hline
\end{tabular}

Data were entered as mean \pm S.E.M of mice. $*$ Statistically significant $(\mathrm{p}<0.05)$.

ARFTG, aqueous residue fraction of Tapinanthus globiferus leaf extract;

CFTG; chloroform fraction of Tapinanthus globiferus leaf extract.

observation may justify the use of water decoction for the extraction of this plant. Earlier, an aqueous residue fraction of a hydroalcoholic Tapinanthus globiferus leaf extract has been reported for anti-convulsant effects in mice and chicks (11).

\section{DISCUSSION}

Extracts of Tapinanthus globiferus are often taken as water decocts for the traditional amelioration of diverse diseases such as hypertension, fevers, cancers, epilepsy, diabetes mellitus and nervous disorders in Sokoto and environs. The use of water extract of this plant by the populace may gain support from the outcome of the fractionation of the hydroalcoholic extract of this plant in this study in which it was found to partition overwhelmingly into the aqueous residue portion with negligible amounts of this plant found in the n-butanol, n-hexane and ethyl acetate fractions. Further support for the traditional use of the water decocts of this plant for alleviation of nervous disorders may also come from the greater anxiolytic activity exhibited by the aqueous residue than the chloroform fraction of this plant in this study.

This finding in this study may be thefirst report of an anxiolytic activity attributable to fractions obtained from Tapinanthus globiferus leaf extracts. The greater anxiolytic activity of the aqueous residue over the chloroform fraction may suggest that more bio-active chemical compounds may have partitioned into the aqueous fraction, and this
A crude aqueous extract of Tapinanthus dodoneifolius (DC) Denser stem bark has also been found to exhibit both anxiolytic and antidepressant activity in experimental mice (13).

Both aqueous residue and chloroform fractions of Tapinanthus globiferus leaf extracts were found to be very safe with LD50 greater than $5000 \mathrm{mg} / \mathrm{kg}$ by oral route in this study. This relative safety may be another factor why this medicinal plant has gained widespread use among the locals in Sokoto and elsewhere. Similar safety toxicity profiles with LD50s greater than $5000 \mathrm{mg} / \mathrm{kg}$ - have been previously reported for a residual aqueous fraction of leaf extract of Ficus glumosa-grown-Tapinanthus globiferus (11) in mice and chicks, for a crude methanol leaf extract of Azadirachta indica-grown Tapinanthus globiferus (18) in mice andTamarindaindica-grown Tapinanthus dodoneifolius(19) in Wistar rats.

In conclusion, the findings of this study indicate that water-based extraction of this plant may be well-suited and that its aqueous residue and chloroform fractions are relatively safe and possess anxiolytic effects in mice. There is 
a need to investigate this plant further for its anti-anxiety efficacy.

\section{REFERENCES}

[1] Begho ER, Omokhafe KO, Omo-Ikerodah EE, Akpaja EO. Some observations on the fruit set and incidence of mistletoes on rubber trees in Nigeria. American-Eurasian Journal of Sustainable Agriculture 2007; 1(1), 13-18.

[2] Adesina SK, Illoh HC, Johnny II, Jacobs IE. African mistletoes (Loranthaceae); ethnopharmacology, chemistry and medicinal values: an update. African Journal of Traditional, Complementary, and Alternative Medicines : AJTCAM 2013; 10: 161-170.

[3] Adodo A. Nature Power, A Christian Approach to Herbal Medicine. 3rd Edition. Benedictine Publication Nigeria;.pp. 103-111. Edo State. Surulere, Lagos: 7th Printing by Generation Press Ltd; 2004.

[4] Ogunmefun OT, Fasola TR, Saba AB, Oridupa OA. The ethnobotanical, phytochemical and mineral analyses of PhragmantheraIncana (Klotzsch), a species of mistletoe growing on three plant hosts in South-western Nigeria. International Journal of Biomedical Science 2013; 9(1): 37-44.

[5] EdagboDE, Ajiboye TO, Borokini TI, Ighere DA, Alowonle AA, Michael C. The influence of THE INFLUENCE OF AFRICAN MISTLETOE (Tapinanthus bangwensis) ON THE CONSERVATION STATUS OF Citrus sinensisin MOOR PLANTATION AREA of IBADAN, NIGERIA. International Journal of Current Research 2012; 4(12): 484-487.

[6] OgbonniaSO, AnyikaEN, MbakaGO, Utah P, Ugwu D, Nwakakwa N, Ota DA. Antihyperglycaemic and antihyperlipidaemic effects of aqueous ethanol extract of Tapinanthus globiferus leaves and Treculia africana root bark and their mixture on alloxan diabetic rats:J. N. Am., 2012, 3(6): 237-246.

[7] Deliorman D, Calis I, Ergun F. Studies: on the vascular effects of the fractions and phenolic compounds isolated from Viscum album ssp album. J Ethnopharmacol. 2000,72: 323-329.

[8] EmaikwuV, Ndukwe, IG, Iyun OR, Anyam JY. Preliminary phytochemical and antimicrobial activity screening of crude extracts of bird lime (Tapinanthus globiferus). Journal of Applied Sciences and Environmental Management 2019;23(2): 305-308.

[9] Akinmoladun AC, Obuotor EM, Farombi EO, Evaluation of antioxidant and free radicalscavenging capacities of some Nigerian Indigenous Medicinal Plants. Journal of Medicinal Food. 2010; 13 (2):444-451.

[10] Patrick-Iwuanyanwu KC, Onyeike EN, Wegwu MO.Hepatoprotective effects ofMethanolic extract and fractions of African mistletoe Tapinanthusbangwensis (Engl. \& $\quad$ K. $\quad$ Krause) from Nigeria. Excli Journal 2010; 9: 187-194.

[11] Abubakar K, Adebisi IM, Ugwah-Oguejiofor JC, Idris G.O., Idris B. and Mshelia H.E.Phytochemical Screening and Anticonvulsant Activity of the Residual Aqueous Fraction of Tapinanthus globiferus Growing on Ficus glums. Herb Med. 2016, 2:2.

[12] ShehuA, Magaji MG, Yau J, Abubakar A. Ethno-botanical survey of medicinal plants used for the management of depression by Hausa tribes of Kaduna State, Nigeria. Journal of Medicinal Plants Research2017;11: 562-567.

[13] HarquinSimplice F, David Emery T. HervéHervé NA. Enhancing spatial memory: Anxiolytic and antidepressant effects of Tapinanthus dodoneifolius (DC) Danser in mice. Neurology Research International, 2014; Article ID 974308, 9 pages.

[14] Thaxter KA, Young LE, Young RE, Parshad O. Addae J. An extract of neem leaves reduces anxiety without causing motor side effects in an experimental model. The West Indian Medical Journal 2010; 59 (3), $245-248$

[15] Kupchan SM, Tsou G, Sigel CW. Datiscacin, a novel cytotoxic cucurbitacin 20-acetate from Datiscaglomerata. J Org Chem. 1973;38(7):1420-1.

[16] Lorke D. A new Approach to Practical Acute Toxicity Testing.Archives of Toxicology Journal 1983; 54: 275-287.

[17] Schmitt U, Hiemke C. Strain differences in open-field and elevated plus-maze behaviour of rats without and with pretest handling. Pharmacology Biochemistry and Behavior 1998;59: 807-811.

[18] Kabiru M.Phytochemical screening and antibacterial activity of the crude extract and fractions of tapinanthus globiferus leaves on the bacterial isolates of a wound.World Journal of Pharmaceutical Research 2017; 6(7): 209-238.

[19] Baso AA, Mudi SY. Evaluation of antiulcer and phytochemical activities of leaf extracts from Tapinanthus dodoneifolius DC.
(Loranthaceae) grown on Tamarindusindica tree. Bayero Journal of Pure and Applied Sciences 2018; 10(1): 392 - 396. 